•编者按・

\title{
生物多样性监测与研究是国家公园保护的基础
}

\author{
米湘成 ${ }^{*}$ \\ (中国科学院植物研究所植被与环境变化国家重点实验室, 北京 100093)
}

\section{Biodiversity monitoring and research are basis of national park conser- vation}

\author{
Xiangcheng $\mathrm{Mi}^{*}$ \\ State Key Laboratory of Vegetation and Environmental Change, Institute of Botany, Chinese Academy of Sciences, Beijing 100093
}

随着经济的发展, 我国逐渐认识到自然环境保 护工作的重要性, 实施了“退耕还林(草)”、“天然林 保护”等系列重大生态工程, 建设了各类保护地, 自 然环境得到恢复。Chen等(2019)发现, 近30年来全球 的植被叶面积在增加, 中国植被仅占全球植被面积 的 $6.6 \%$, 却为全球植被叶面积净增长贡献了 $25 \%$, 且中国的植被叶面积增长的 $42 \%$ 来自森林。这一结果 与我国八次森林资源清查的结果一致, 我国森林覆 盖率已经由1976年的12.8\%提高到2013年的21.63\%, 人工林蓄积量提高了15倍(许传德, 2014)。在天然植 被保护方面, 到2016年底我国各类自然保护地已达 1.15 万处之多, 占国土面积 $18 \%$ 以上 (彭杨靖等, 2018)。但是, 我国的自然保护地体系对珍稀濒危的 哺乳动物和鸟类的栖息地覆盖程度比较高, 而对珍 稀濒危植物、两栖和爬行动物的生境, 以及水源涵 养、土壤保持、防风固沙与碳固定等主要生态服务 功能的关键区域覆盖比例较低(Xu et al, 2017b)。这些 没有被保护地覆盖的生物多样性或生态系统服务功 能的关键地区往往是原生或干扰较少的生态系统, 它们所提供的服务功能远高于次生或人工生态系统 (Watson et al, 2018), 因此我国保护地体系需要进一 步完善顶层设计。另一方面, 我国10类保护地之间存 在着管理交叉重叠、生态系统碎片化等问题, 影响生 态系统的完整性(唐小平, 2014; 钟林生等, 2016)。针 对这些问题, 党的十八届三中全会提出了建立国家 公园体制, 并于2017年9月发布了《建立国家公园体
制总体方案》，尝试“建立以国家公园为主体的自然 保护地体系”, 提出了“生态保护第一、国家代表性、 全民公益性”的三大理念(马克平, 2017; 杨锐, 2017)。

国家公园是具有国家代表性的、大面积重要的 自然或接近自然的生态系统, 同时具有独特的自然 景观和丰富的科学内涵(马克平, 2014), 保护其完整 性和原真性成为建立国家公园的首要目标。对生态 系统和生物多样性的监测和研究, 是国家公园内大 面积自然生态系统保护的基础。

首先, 长期监测和研究将进一步加深人们对生 态系统的理解和认识, 使国家公园的管理和规划建 立在坚实的科学基础之上。我国20世纪80年代开始 逐步建立长期定位研究网络, 到2004年建成了国家 生态系统观测研究网络, 虽然取得明显进展, 但目 前人们对生态系统长期动态过程的认识还相当有 限。例如在黄石国家公园, 人们经过长期研究发现: 因为干扰和气候变化, 公园内的生态系统在不断变 化中, 一些原来看似有破坏性的因素(如森林火灾) 却能增加生态系统的异质性和对入侵的抵御能力。 国家公园原定的目标从而由保护自然或原始状态 的生态系统转变为保护生态过程(Wallace, 2004)。针 对国家公园内的典型生态系统进行长期监测和研 究, 会不断加深人们对这些生态系统的认识, 优化 和更新国家公园保护的目标和策略。

第二, 遥感和地面监测相结合使得对国家公园 大尺度长期监测成为可能。传统的地面监测方法费

* 通讯作者 Author for correspondence. E-mail: mixiangcheng@ibcas.ac.cn 
时费力, 难以对大面积的生态系统过程进行连续监 测。但大尺度生态系统过程(如: 动物的迁徙、火灾) 有时甚至超出国家公园的范围, 为了保护动物廊道, 北美倡导了沿落基山脉从黄石公园到加拿大育空 省的3,500 $\mathrm{km}$ 黄石一育空保护行动(Yellowstone to Yukon Conservation Initiative, Y2Y) (Chester \& Hilty, 2019)。随着遥感技术的发展, 近地面遥感开始应用 于长期监测国家公园大尺度生态系统过程。如 Soulard等(2016)利用遥感手段监测了加州的优胜美 地国家公园(Yosemite National Park)内火灾对山地 草甸的影响, 逐月比较了1985-2012年26个火烧草 甸和没有火干扰草甸的LandSat卫星NDVI (归一化 植被指数)变化趋势, 发现火烧草甸周边的常绿植 被已经被1996年的火灾所破坏而无法恢复。Xu等 (2017a)利用遥感手段发现, 虽然我国大熊猫国家公 园的大熊猫濒危等级已经从濒危降为易危, 但其 2013年的栖息地比1988年破碎化程度更高。

此外, 分子、红外相机等手段也能应用于监测。 例如: Sawaya等(2014)在加拿大的班夫国家公园采 用分子生物学方法分析了棕熊(Ursus arctos)和黑熊 (U. americanus)的种群遗传结构, 发现 $47 \%$ 的黑熊 和 $27 \%$ 的棕熊利用了野生动物通道, 证明野生动物 通道有利于恢复因为公园内道路阻隔造成的种群 间的遗传隔离。在我国虎豹国家公园采用2,000台红 外相机监测着27只东北虎(Panthera tigris altaica)和 42只远东豹 ( P. pardus orientalis)的种群动态, 而尚 未利用的东北虎潜在栖息地基本在中国境内 (McLaughlin, 2016)。

钱江源国家公园体制试点区 (以下简称钱江源 国家公园)作为我国亚热带常绿阔叶林地区国家公 园体制试点的样本, 保存着罕见的大面积低海拔、 地带性的典型常绿阔叶林, 国家二级重点保护野生 植物长柄双花木 (Disanthus cercidifolius var. longipes)的天然种群面积达5,000多亩, 栖息着国家 一级重点保护野生动物黑鹿(Muntiacus crinifrons) 和白颈长尾雉(Syrmaticus ellioti), 既是典型生态系 统的保护地, 也成为亚热带常绿阔叶林生态系统和 生物多样性维持机制研究的理想平台。2005年中国 科学院植物研究所联合浙江大学和浙江师范大学 等在钱江源国家公园建立了 $24 \mathrm{ha}$ 森林动态样地, 开 启了长期定位研究。经过多年的努力, 在这里建立 了 4 个生态系统和生物多样性监测和研究平台:
(1)全境森林动态样地监测平台。包含 1 个 24 ha 样地、14个 $1-5$ ha样地和约 600 个分布于全境 $1 \mathrm{~km} \times$ $1 \mathrm{~km}$ 网格的 $20 \mathrm{~m} \times 20 \mathrm{~m}$ 或 $30 \mathrm{~m} \times 30 \mathrm{~m}$ 样方。对样地 内胸径 $\geq 1 \mathrm{~cm}$ 的植株挂牌、定位、测量胸径并鉴定 到种; 每5年复查一次, 监测亚热带森林生态系统 和生物多样性的变化(祝燕等, 2008)。

(2)全境网格化动物多样性监测平台。把整个国 家公园划分为 268 个 $1 \mathrm{~km} \times 1 \mathrm{~km}$ 网格, 每个网格内布 设红外相机和自动录音设备, 监测大型兽类、雉类和 森林鸣禽的多样性和种群动态(余建平等, 2019)。

(3)森林冠层生物多样性监测平台。由一个高度 为 $60 \mathrm{~m}$ 、塔臂长度为 $60 \mathrm{~m}$ 的塔吊系统组成, 以塔吊 为中心建立 $140 \mathrm{~m} \times 160 \mathrm{~m}$ 的样地, 用以监测林冠生 物多样性格局动态和生态学过程。

(4)亚热带森林生物多样性与生态系统功能实验 平台(简称BEF平台)。该平台是由中国、德国和瑞士 三国科学家联合建立的、世界上唯一在亚热带森林 的BEF平台。BEF平台的主实验样地由两块样地构成, 分为 566 个 1 亩的小样地, 总面积 $40 \mathrm{ha}$, 种植约 30 万 株苗木, 实验乔木物种丰富度设置为 6 级: $0 、 1 、 2 、 4 、$ $8 、 16$, 灌木物种丰富度设置为 4 级： $0 、 2 、 4 、 8$ (Bruelheide et al, 2014)。该平台旨在研究亚热带森林 生物多样性与生态系统功能的关系及其作用机制。

钱江源国家公园可以作为国家公园与科研院 所和大专院校联合开展监测和研究的重要基地。这 些平台已吸引了众多的科研院所联合展开研究。本 期“钱江源国家公园生物多样性保护与管理专辑”报 道上述平台的部分研究成果, 并针对钱江源国家公 园集体林占比高、科学管控难, 存在着自然保护与 社区发展冲突等问题，从农户生计资本、地役权和 跨界管理等方面探讨了国家公园的体制建设、社区 共管等问题。利用全境网格化动物多样性监测平台 红外相机的监测数据, 余建平等(2019)评估了钱江 源国家公园的功能分区对黑鹿保护的有效性, 任鹏 等(2019)发现了白颈长尾雉的分布格局是由水源和 海拔等多个环境变量共同决定, 温度的变化和对不 同海拔段的选择是造成季节分布格局的主要原因。 利用全境森林动态样地监测平台, 池秀莲等(2019) 发现, 古田山常绿阔叶林萌生能力随林分年龄的增 大而下降, 且受海拔、坡向等地形因素的影响。翁 昌露等(2019)发现海拔和群落类型是古田山森林群 落 $\alpha$ 和 $\beta$ 多样性的主要影响因子, 表明生境过滤等在 
群落生物多样性维持中的重要作用。钱海源等(2019) 介绍了钱江源国家公园鸟类多样性与区系组成, 发 现鸟类种数占全省的 $52 \%$, 在鸟类保护中有重要作 用。李通等(2019)分析了古田山森林木腐真菌的物 种组成和地理成分, 发现林分中倒木直径大小和腐 烂程度是影响木腐真菌生长与分布的重要因子。李 杰等(2019)利用近地面遥感技术结合实地植被调查, 评估了钱江源国家公园现有分区存在的主要问题, 为国家公园合理的功能区划提供了一种可行的方 法。孙孝平等(2019)模拟了到2025年4种可能的土地 利用策略情景下，钱江源国家公园的生态系统服务 及其价值的变化, 为国家公园管理的科学决策提供 了理论支持。李双等(2019)分析了农户生计资本和 空间分布特征，提出改善区内农户生计状况的建议， 试图缓解自然保护与社区居民发展可能的冲突; 王 宇飞等(2019)设计了一套基于细化保护需求的保护 地地役权制度, 进行适应性管理, 试图解决我国南 方自然保护地集体林占比高等问题; 张晨等(2019) 建议借鉴法国大区公园经验, 形成一个政府主导, 企业、社区居民和第三方组织共同参与的多元主体 协同治理组织框架, 来解决国家公园跨界管理存在 的行政区划碎片化和管理分割的问题。最后，代云 川等(2019)综述了国家公园生态系统完整性评价的 三种主要方法，同时探讨了目前国家公园生态系统 完整性评价中存在的一些问题, 提出需要注重自然 -经济-社会的结合与统一。

\section{参考文献}

Bruelheide H, Nadrowski K, Assmann T, Bauhus J, Both S, Buscot F, Chen X-Y, Ding B, Durka W, Erfmeier A, Gutknecht JLM, Guo D, Guo L-D, Härdtle W, He J-S, Klein A-M, Kühn P, Liang Y, Liu X, Michalski S, Niklaus PA, Pei K, Scherer-Lorenzen M, Scholten T, Schuldt A, Seidler G, Trogisch S, von Oheimb G, Welk E, Wirth C, Wubet T, Yang X, Yu M, Zhang S, Zhou H, Fischer M, Ma K, Schmid B (2014) Designing forest biodiversity experiments: General considerations illustrated by a new large experiment in subtropical China. Methods in Ecology and Evolution, 5, 74-89.

Chen C, Park T, Wang X, Piao S, Xu B, Chaturvedi RK, Fuchs R, Brovkin V, Ciais P, Fensholt R, Tømmervik H, Bala G, Zhu Z, Nemani RR, Myneni RB (2019) China and India lead in greening of the world through land-use management. Nature Sustainability, 2, 122-129.

Chester CC, Hilty JA (2019) The Yellowstone to Yukon Conservation Initiative as an adaptive response to climate change. In: Handbook of Climate Change and Biodiversity (eds Leal Filho W, Barbir J, Preziosi R), pp. 179-193. Springer International Publishing, Cham.

Chi XL, Wang QG, Guo Q, Yang X, Tang ZY (2019) Sprouting characteristics of communities during succession in an evergreen broad-leaved forest on Gutian Mountain, East China. Biodiversity Science, 27, 24-32. (in Chinese with English abstract) [池秀莲, 王庆刚, 郭强, 杨弦, 唐志尧 (2019) 古田山常绿阔叶林不同演替群落的萌生特征. 生 物多样性, 27, 24-32.]

Dai YC, Xue YD, Zhang YY, Li DQ (2019) Summary comments on assessment methods of ecosystem integrity for national parks. Biodiversity Science, 27, 104-113. (in Chinese with English abstract) [代云川, 薛亚东, 张云毅, 李迪强 (2019) 国家公园生态系统完整性评价研究进展. 生物多 样性, 27, 104-113.]

Li J, Li WY, Fu J, Gao J, Yang L, He WH (2019) Using low-altitude UAV remote sensing to identify national park functional zoning boundary: A case study in Qianjiangyuan National Park pilot. Biodiversity Science, 27, 42-50. (in Chinese with English abstract) [李杰, 李巍岳, 付晶, 高峻, 杨 蕾, 何苇航 (2019) 基于近低空遥感技术的国家公园功 能分区边界识别: 以钱江源国家公园体制试点区为例. 生 物多样性, 27, 42-50.]

Li S, Sun XP, Fang YJ, Zhang YL, Cao MC (2019) Evaluation of the spatial characteristics of farmer livelihood assets in the Qianjiangyuan National Park pilot. Biodiversity Science, 27, 64-75. (in Chinese with English abstract) [李双, 孙孝 平, 方彦君, 张银龙, 曹铭昌 (2019) 钱江源国家公园体 制试点区农户生计资本评价及其空间特征. 生物多样性, 27, 64-75.]

Li T, Li JN, Wei YL (2019) Species diversity and distribution of wood-decaying fungi in Gutianshan National Nature Reserve. Biodiversity Science, 27, 81-87. (in Chinese with English abstract) [李通, 李俊凝, 魏玉莲 (2019) 古田山 国家级自然保护区木腐真菌物种多样性及分布. 生物多 样性, 27, 81-87.]

Ma KP (2014) Nature conservation is the first priority for a national park. Biodiversity Science, 22, 415-417. (in Chinese) [马克平 (2014) 国家公园首先是自然保护基地. 生 物多样性, 22, 415-417.]

Ma KP (2017) A significant achievement in the development of national parks in China. Biodiversity Science, 25, 1031-1032. (in Chinese) [马克平 (2017) 中国国家公园建 设取得标志性进展. 生物多样性, 25, 1031-1032.]

McLaughlin K (2016) Tiger land. Science, 353, 744-745.

Peng YJ, Fan J, Xing SH, Cui GF (2018) Overview and classification outlook of natural protected areas in mainland China. Biodiversity Science, 26, 315-325. (in Chinese with English abstract) [彭杨靖, 樊简, 邢韶华, 崔国发 (2018) 中国大陆自然保护地概况及分类体系构想. 生物多样性, 26, 315-325.]

Qian HY, Yu JP, Shen XL, Ding P, Li S (2019) Diversity and composition of birds in the Qianjiangyuan National Park pilot. Biodiversity Science, 27, 76-80. (in Chinese with 
English abstract) [钱海源, 余建平, 申小莉, 丁平, 李晟 (2019) 钱江源国家公园体制试点区乌类多样性与区系组 成. 生物多样性, 27, 76-80.]

Ren P, Yu JP, Chen XN, Shen XL, Song X, Zhang TT, Yu YQ, Ding P (2019) Seasonal variation in the distribution of Elliot's pheasant (Syrmaticus ellioti) in Gutianshan National Nature Reserve. Biodiversity Science, 27, 13-23. (in Chinese with English abstract) [任鹏, 余建平, 陈小南, 申小 莉, 宋虓, 张田田, 余永泉, 丁平 (2019) 古田山国家级 自然保护区白颈长尾雉的分布格局及其季节变化. 生物 多样性, 27, 13-23.]

Sawaya MA, Kalinowski ST, Clevenger AP (2014) Genetic connectivity for two bear species at wildlife crossing structures in Banff National Park. Proceedings of the Royal Society B: Biological Sciences, 281, 20131705.

Soulard CE, Albano CM, Villarreal ML, Walker JJ (2016) Continuous 1985-2012 LandSat monitoring to assess fire effects on meadows in Yosemite National Park, California. Remote Sensing, 8, 371.

Sun XP, Li S, Yu JP, Fang YJ, Zhang YL, Cao MC (2019) Evaluation of ecosystem service value based on land use scenarios: A case study of Qianjiangyuan National Park pilot. Biodiversity Science, 27, 51-63. (in Chinese with English abstract) [孙孝平, 李双, 余建平, 方彦君, 张银龙, 曹铭昌 (2019) 基于土地利用变化情景的生态系统服务 价值评估：以钱江源国家公园体制试点区为例. 生物多 样性, 27, 51-63.]

Tang XP (2014) On the system of national parks and the path of development in China. Biodiversity Science, 22, 427-430. (in Chinese) [唐小平 (2014) 中国国家公园体制 及发展思路探析. 生物多样性, 22, 427-430.]

Wallace LL (2004) After the Fires: The Ecology of Change in Yellowstone National Park. Yale University Press, Yale University Press. New Haven and London.

Wang YF, Su HQ, Zhao XR, Su Y, Luo M (2019) Conservation easement-inspired adaptive management methods for natural protected areas: A case study on Qianjiangyuan National Park pilot. Biodiversity Science, 27, 88-96. (in Chinese with English abstract) [王宇飞, 苏红巧, 赵金蒡, 苏 杨, 罗敏 (2019) 基于保护地役权的自然保护地适应性管 理方法探讨: 以钱江源国家公园体制试点区为例. 生物多 样性, 27, 88-96.]

Watson JEM, Evans T, Venter O, Williams B, Tulloch A, Stewart C, Thompson I, Ray JC, Murray K, Salazar A, McAlpine C, Potapov P, Walston J, Robinson JG, Painter M, Wilkie D, Filardi C, Laurance WF, Houghton RA, Maxwell S, Grantham H, Samper C, Wang S, Laestadius L, Runting RK, Silva-Chávez GA, Ervin J, Lindenmayer D (2018) The exceptional value of intact forest ecosystems. Nature Ecology \& Evolution, 2, 599-610.

Weng CL, Zhang TT, Wu DH, Chen SW, Jin Y, Ren HB, Yu MJ, Luo YY (2019) Drivers and patterns of $\alpha$ - and $\beta$-diversity in ten main forest community types in Gutianshan National Nature Reserve, eastern China. Biodiversity Science, 27, 33-41. (in Chinese with English abstract) [翁昌露, 张
田田, 巫东豪, 陈声文, 金毅, 任海保, 于明坚, 罗媛媛 (2019) 古田山10种主要森林群落类型的 $\alpha$ 和 $\beta$ 多样性格局 及影响因素. 生物多样性, 27, 33-41.]

Xu CD (2014) Forest management in China from eight forest resources inventories. Forest Economics, 4, 8-11. (in Chinese with English abstract) [许传德 (2014) 从连续八次森 林资源清查数据看我国森林经营. 林业经济, (4), 8-11.]

Xu W, Viña A, Kong L, Pimm SL, Zhang J, Yang W, Xiao Y, Zhang L, Chen X, Liu J, Ouyang Z (2017a) Reassessing the conservation status of the giant panda using remote sensing. Nature Ecology \& Evolution, 1, 1635-1638.

Xu W, Xiao Y, Zhang J, Yang W, Zhang L, Hull V, Wang Z, Zheng H, Liu J, Polasky S, Jiang L, Xiao Y, Shi X, Rao E, Lu F, Wang X, Daily GC, Ouyang Z (2017b) Strengthening protected areas for biodiversity and ecosystem services in China. Proceedings of the National Academy of Sciences, USA, 114, 1601-1606.

Yang R (2017) Conservation first, national representative, and commonwealth: the three concepts of China's National Park System Construction. Biodiversity Science, 25, 1040-1041. (in Chinese) [杨锐 (2017) 生态保护第一、国家代表性、 全民公益性一一国国家公园体制建设的三大理念. 生 物多样性, 25, 1040-1041.]

Yu JP, Shen YY, Song XY, Chen XN, Li S, Shen XL (2019) Evaluating the effectiveness of functional zones for black muntjac (Muntiacus crinifrons) protection in Qianjiangyuan National Park pilot site. Biodiversity Science, 27, 5-12. (in Chinese with English abstract) [余建平, 申云逸, 宋小友, 陈小南, 李晟, 申小莉 (2019) 钱江源国家公园体制试点区功能 分区对黑鹿保护的有效性评估. 生物多样性, 27, 5-12.]

Zhang C, Guo X, Weng ST, Gao J, Fu J (2019) Cross-border governance system construction of Qianjiangyuan National Park pilot by referring to the experience of French regional parks. Biodiversity Science, 27, 97-103. (in Chinese with English abstract) [张晨, 郭金金, 翁苏桐, 高峻, 付晶 (2019) 法国大区公园经验对钱江源国家公园体制试点区跨界治 理体系构建的启示. 生物多样性, 27, 97-103.]

Zhong LS, Deng Y, Chen T, Tian CD (2016) New regional space-Discussion on construction of national park system. Bulletin of Chinese Academy of Sciences, 31, 126-133. (in Chinese with English abstract) [钟林生, 邓羽, 陈田, 田长 栋 (2016) 新地域空间—国家公园体制构建方案讨论. 中国科学院院刊, 31, 126-133.]

Zhu Y, Zhao GF, Zhang LW, Shen GC, Mi XC, Ren HB, Yu MJ, Chen JH, Chen SW, Fang T, Ma KP (2008) Community composition and structure of Gutianshan forest dynamics plot in a mid-subtropical evergreen broad-leaved forest, East China. Chinese Journal of Plant Ecology, 32, 262-273. (in Chinese with English abstract) [祝燕, 赵谷风, 张俪文, 沈 国春, 米湘成, 任海保, 于明坚, 陈建华, 陈声文, 方腾, 马克平 (2008) 古田山中亚热带常绿阔叶林动态监测样 地一一群落组成与结构. 植物生态学报, 32, 262-273.] 